IRA-International Journal of Management \& Social Sciences

ISSN 2455-2267; Vol.07, Issue 02 (2017)

Pg. no. 320-328

Institute of Research Advances

http://research-advances.org/index.php/RAJMSS

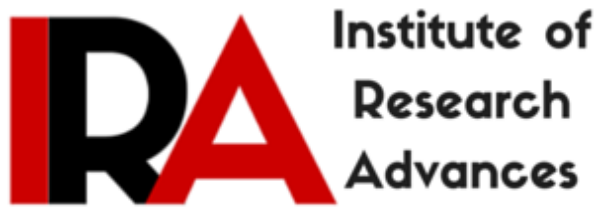

\title{
Interpersonal Conflict Management- Inevitable but Manageable (with Reference to M/S Karvy Computershare Pvt. Ltd, Hyderabad \& M/S Anand Rathi, Bangalore)
}

Dr. Nagaraju Battu

Head - Dept of HRM, Acharya Nagarjuna University, Guntur, Andhra Pradesh, India.

Ch. R.B. Alias Kalyan Ram

Research Scholar, Dept of HRM, Acharya Nagarjuna University, Guntur, Andhra Pradesh, India.

Type of Review: Peer Reviewed.

DOI: http://dx.doi.org/10.21013/jmss.v7.n2.p23

\section{How to cite this paper:}

Battu, N., \& Kalyan Ram, C. (2017). Interpersonal Conflict Management- Inevitable but Manageable (with Reference to M/S Karvy Computershare Pvt. Ltd, Hyderabad \& M/S Anand Rathi, Bangalore). IRA-International Journal of Management \& Social Sciences (ISSN 24552267), 7(2), 320-328. doi:http://dx.doi.org/10.21013/jmss.v7.n2.p23

(C) Institute of Research Advances

\section{(c)) EY-NO}

This work is licensed under a Creative Commons Attribution-Non Commercial 4.0 International License subject to proper citation to the publication source of the work.

Disclaimer: The scholarly papers as reviewed and published by the Institute of Research Advances (IRA) are the views and opinions of their respective authors and are not the views or opinions of the IRA. The IRA disclaims of any harm or loss caused due to the published content to any party. 


\begin{abstract}
Introduction: A conflict has generally been defined as a situation in which two or more parties strive to acquire the same scarce resources at the same time. Scholars generally agree that there needs to be more than one part to have a conflict, and that the time factor is important. What does cause concern is the term scarce resource.

Objective of the Study: To examine the effect of strategies adopted for managing interpersonal conflict on organizational performance, to examine the perceptions of the employees in the organization under study and to offer suggestions to minimize the inter-personal conflicts and to improve conducive environment for organizational success

Method of the Study: The study employed both descriptive survey design and explanatory research design. It targeted a population of 650 employees of purposively selected units under study. A sample size comprising 450 employees from M/s Karvy Computershare and 200 from M/s Anand Rathi were selected using stratified random sampling techniques.

Results of the Study: Conflict escalation has according to this study it's foundation in emotional involvement. A person focused conflict has a higher risk of escalation and to evolve towards becoming dysfunctional. Through this study it has been revealed that conflict management can be divided into two areas, prevention of conflicts and management of functional conflicts. Feedback can be counted as preventive tools to help develop employee's behaviour and to ensure that the opinions and feelings are passed on through controlled communication channels.
\end{abstract}

Keywords: Conflict, Empowerment, managing interpersonal conflict, Managers, Executives.

\title{
INTRODUCTION
}

A conflict has generally been defined as a situation in which two or more parties strive to acquire the same scarce resources at the same time. Scholars generally agree that there needs to be more than one part to have a conflict, and that the time factor is important. What does cause concern is the term scarce resource. The central point in this argument is scarcity, but resources need also be included in the discussion. Peter Wallensteenq has pointed out that resources are not only economic in nature, and that the terminology might miss conflicts involving economic orientation, human security, environment, historical issues, etc. Such conflicts are not necessarily about resources, and when they are, these resources are, more importantly, not necessarily scarce. A conflict is, moreover, in many cases based on perceptions, rather than on attitudes or behavior as it has generally been defined.

\section{CONFLICT MANAGEMENT - CONCEPTUAL BACKGROUND}

Conflict has both positive and negative effects. It can be positive when it encourages creativity, new looks at old conditions, the clarification of points of view, and the development of human capabilities to handle interpersonal differences. Unfortunately, the term "conflict" has only the connotation of "bad" for many people; so much so that they think principally in terms of suppression, giving little or no attention to its more positive side. Rico emphasizes this by stating that it seems entirely likely that many, if not most, organizations need more conflict, not less.

Tjosvold (1998) complements this statement arguing that conflict is not the opposite of cooperation but a mechanism that allows perceiving benefits of cooperative work. Furthermore, conflict is considered psychologically and socially healthy. It is psychologically healthy because it provides a breather for frustrations and enables a feeling of participation and even of joy. And it is sociable healthy because it encourages opposition to the status quo and provides conditions for social chances and democracy stemming from pluralism and respect to diversity. Therefore, conflict is ubiquitous, not necessarily dysfunctional and can be required to defy people to perform and stimulate progress.

\section{SIGNIFICANCE OF THE STUDY}

The conflict resolution strategies that were considered in this study include avoiding, smoothing, forcing, compromising and confronting strategies. Avoiding strategy involves physical removal of 
oneself from conflict. Shows minimal concern for both parties involved in conflict and mostly results in a lose-lose situation between employees and employers. Smoothing strategy involves putting great emphasis on the concern for one's own detriment while accommodating the other party's concerns. Here neither the management nor the superiors loses or wins. Confronting strategy involves handling conflict directly and solving it to a mutually satisfactory resolution. Here both the management and the employees win. According to Newstrom (2007) in most organizations conflict among different parties is unavoidable and sometimes the amount of conflict is essential. Therefore it is important for management to employ different conflict resolution strategies to encourage harmony and good working relationship with employees.

\section{REVIEW OF LITERATURE}

Mooney (2014) affirmed that conflict naturally arises when employees are discriminated against based on their gender. Workers can have problems relating to one another when there is unfair treatment by management to certain employees. Workers might argue instances of bias as they fight for equality in their place of employment. For example, if a male employee is junior to a female employee but is still promoted ahead of her, it will probably be difficult for the woman to accept this man as a supervisor, and she might argue with management regarding this decision.

Miller and Vaske (2015) used survey analysis to measure the changes in reported interpersonal and social values conflict over a more than 10-year period at the Vail Pass Winter Recreation Area (VPWRA) in central Colorado. The results showed interpersonal conflict decreased over the period for both non-motorized and motorized recreationists. Both groups, however, continue to report interpersonal conflict even with an established zoning system. Despite an established active management approach at the VPWRA, social values conflict among non-motorized recreationists increased over the period. One important finding was that despite a system of zoning at the VPRWA, there are areas with both non-motorized and motorized recreationists present. These mixed-use areas, it was hypothesized, may have been responsible for the lingering interpersonal and social values conflict.

\section{STATEMENT OF THE PROBLEM}

The management of M/s Karvy Computershare and M/s Anand Rathi feels that the total qualitative productivity in terms of customer/investor services satisfaction of their companies can be further enhanced as per the demand of the Industry requirement. Moreover, researcher argues that companies selected under study have suffered, and are still suffering from the phenomenon of conflict either between individuals or between groups, departments and organizations. This concept is supported by experts who suggest that the factors causing all types of organizational conflict need to be studied in-depth in the M/s Karvy Computershare and M/s Anand Rathi units.

M/s Karvy Computershare and M/s Anand Rathi companies have consistently faced many problems, such as managerial, technical and financial problems, which have led to low productivity and customer/investor services. Based on the perceived relationship between performance and organizational conflicts, Interpersonal Conflict may be one of the managerial problems causing interpersonal conflict [IPC] in the selected units of the study and will not address the factors that cause other types of Organizational conflict. Thus, this research gap [research problem] has been identified as there is no known existence of any research under taken on the factors causing IPC in the selected units under study.

\section{OBJECTIVES OF THE STUDY}

The objectives of the present study are proposed of the following objectives:

- To examine the effect of strategies adopted for managing interpersonal conflict on organizational performance.

- To examine the perceptions of the employees in the organization under study. 
- To offer suggestions to minimize the inter-personal conflicts and to improve conducive environment for organizational success.

\section{HYPOTHESIS OF PRESENT STUDY}

In line with the objectives stated above, the following hypotheses were formulated and tested for the purpose of the study.

$\mathrm{H}_{1}$ : Strategies adopted for managing interpersonal conflict do not significantly affect organizational performance.

\section{METHODOLOGY OF STUDY \\ Research Design}

In pursuance of the above mentioned objectives and hypotheses, the following methodology was adopted for the study. It is an empirical method based on both primary and secondary data. The first objective of the study was pursued by the collection and analysis of data from secondary sources whereas all the other objectives have been achieved by collection and analysis of primary data.

\section{Sample Design}

The study follows proportionate sampling design. The list of sampling units and sample respondents status wise is given as follows:

Table: 3.1

\begin{tabular}{|c|c|c|c|c|c|c|}
\hline \multirow{2}{*}{$\underset{\text { G }}{\text { SAMPLIN }}$} & \multicolumn{3}{|c|}{ M/S KARVY COMPUTERSHAR } & \multicolumn{3}{|c|}{ M/S ANAND RATHI } \\
\hline & $\begin{array}{c}\text { MANAGER } \\
\text { S }\end{array}$ & EXECUTIVES & $\begin{array}{c}\text { TOTA } \\
\text { L }\end{array}$ & $\begin{array}{l}\text { MANAGER } \\
\mathbf{S}\end{array}$ & $\begin{array}{l}\text { EXECUTIVE } \\
\mathrm{S}\end{array}$ & $\begin{array}{c}\text { TOTA } \\
\text { L }\end{array}$ \\
\hline UNIVERSE & 255 & 1990 & 2245 & 137 & 863 & 1000 \\
\hline SAMPLE & 50 & 400 & 450 & 27 & 173 & 200 \\
\hline
\end{tabular}

The study follows proportionate sampling design, the researcher could not select sample randomly because the risk that the respondents randomly selected might not cooperate in data collection. Since reliable data willingly provided by the respondents is very crucial for the study, the researcher has selected samples based on their willingness to provide data. Hence, to study the sampling adequacy

\section{Data Collection}

This study consists of primary data that are the responses from employees obtained through the questionnaire. The secondary data in this study was represented by the various relevant studies previously conducted and was referred in most of the chapters in this study. The tertiary data in this study comprises of Bibliography and other indexes.

Since, the researcher has already served in the organization under study, got ample opportunities to mingle with all the cadres of employees. Also, the researcher had actually experienced the working conditions, environment, culture, change and also other problems among the employees, regarding adapting to the recent technological developments. These factors prompted me to feel about the Interpersonal Conflict (IPC) Management concept in the organization. These factors enlightened me to make an attempt to study the effect of the conflict management in the organization and felt that this may expose the pros and cons of the IPC prevailing at present. Taking the line on the above aspects, the experience and the knowledge gathered in the organization made me to construct the questionnaire tool, on his own.

The researcher also conducted a pilot study among 60 employees of the sample organizations. He observed that the employees found the questionnaire devoid of ambiguity and had abundant clarity of purpose and it was easy to respond in minimum duration. 


\section{LIMITATIONS OF STUDY}

The proposed study is confined to

- The research work has been carried out only in few selective Offices of selected units and the findings may not be applicable to the other branches.

- The sample has been collected using random-sampling technique. As such result may not give an exact representation of the population.

- Normally, employees hesitate to disclose the information so it leads to preconception.

\section{RESULTS AND DISCUSSION}

Based on the findings from this study, the researcher recommends the following suggestions. Here are some methods in life skills to effectively deal with interpersonal conflict. Conflict resolutions in this study provide some effective interpersonal communication skills:

Efforts should be made by the managers to occasionally stimulate constructive task conflict by encouraging divergent views and rewarding staff and department for outstanding performance while relationship conflict should be completely prevented.

Outcomes of interpersonal conflict should not be overlooked by managers and accounted for as part of the normal outcomes of doing business but should be minimized by clarifying to staff at large where to go for advice in case of conflict and build peer-support structure of conflict advisors.

Managers should develop diverse but appropriate strategies to resolve and manage conflicts as they arise before escalating to unmanageable level.

Proper communication procedures should be put in place to resolve conflict. For instance, when any disagreement arises among the employees, it should be reported to the management and then management should get statements from the parties involved, brainstorm the issue and make recommendations on how to resolve the conflict for better work culture and ethos.

TABLE 2.1: DATA ANALYSIS RESULT VALUES USING MEAN, STANDARD DEVIATION, MEAN DEVIATION TECHNIQUE AMONG MANAGERS AND EXECUTIVES OPINIONS OF BOTH M/S KARVY COMPUTERSHARE \&M/S ANAND RATHI UNITS

\begin{tabular}{|c|c|c|c|c|c|}
\hline $\begin{array}{l}\text { S. } \\
\text { No }\end{array}$ & Statements & Mean & $\begin{array}{l}\text { Standard } \\
\text { deviation }\end{array}$ & $\begin{array}{c}\text { Mean } \\
\text { deviation }\end{array}$ & Result inference \\
\hline 1 & RUSHED EVEN UNDER PRESURE & 81.25 & 41.74 & 34.625 & High Deviation \\
\hline 2 & TAKE THINGS ONE AT A TIME & 81.25 & 48.79 & 41.06 & High Deviation \\
\hline 3 & SLOW IN DOING THINGS & 81.25 & 57.55 & 51.25 & High Deviation \\
\hline 4 & ABILITY TO ACKNOWLEDGE MISTAKES & 81.25 & 27.14 & 23.06 & High Deviation \\
\hline 5 & $\begin{array}{llll}\text { MAINTAINS } & \text { POLITNESS } & \text { IN } & \text { ANY } \\
\text { INTERACTION } & & & \\
\end{array}$ & 81.25 & 33.64 & 25.37 & High Deviation \\
\hline 6 & MANY INTERESTS & 81.25 & 44.86 & 38.31 & High Deviation \\
\hline 7 & CONFLICT RESOLUTION BEHAVIOUR & 81.25 & 56.09 & 46.25 & High Deviation \\
\hline 8 & $\begin{array}{lrlll}\text { DIFFICULT TO IMITATE } & \text { THE } & \text { ACTION } & \text { OF } \\
\text { OTHER PEOPLE } & & & & \\
\end{array}$ & 325 & 156 & 156 & High Deviation \\
\hline 9 & 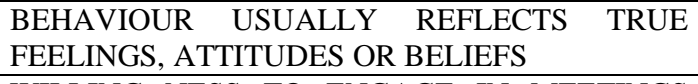 & 325 & 291 & 291 & Low Deviation \\
\hline 10 & $\begin{array}{l}\text { WILLING NESS TO ENGAGE IN MEETINGS } \\
\text { AND SOCIAL GATHERING }\end{array}$ & 325 & 21 & 21 & High Deviation \\
\hline 11 & $\begin{array}{l}\text { SPEECH ON ALMOST ANY TOPIC - EVEN } \\
\text { KNOWN VERY LITTLE }\end{array}$ & 325 & 31 & 31 & High Deviation \\
\hline 12 & $\begin{array}{lccc}\text { ABILITY TO THINK } & \text { ON ONES } & \text { FEET AND } \\
\text { RESPOND } & \text { WITH } & \text { CREDIBLE } & \text { CHOICES, } \\
\text { ALTERNATIVES AND IDEAS } & \\
\end{array}$ & 325 & 238 & 238 & High Deviation \\
\hline
\end{tabular}


IRA-International Journal of Management \& Social Sciences

\begin{tabular}{|c|c|c|c|c|c|}
\hline 13 & $\begin{array}{l}\text { SOMETIMES PUT ON A SHOW TO IMPRESS OR } \\
\text { ENTERTAIN PEOPLE }\end{array}$ & 325 & 62 & 62 & High Deviation \\
\hline 14 & $\begin{array}{l}\text { ACCEPTING THE VIEWS OF THE OTHERS, } \\
\text { RATHER THAN ROCK THE BOAT }\end{array}$ & 325 & 254 & 254 & High Deviation \\
\hline 15 & 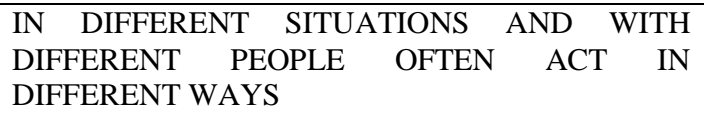 & 325 & 155 & 155 & High Deviation \\
\hline 16 & $\begin{array}{l}\text { ATTITUDE OR ACTIONS WITH NOT CHANGE } \\
\text { TO PLEASE OTHER PEOPLE OR WIN THEIR } \\
\text { APPROVAL }\end{array}$ & 325 & 55 & 55 & High Deviation \\
\hline 17 & $\begin{array}{lccc}\text { SOMETIMES } & \text { PEOPLE } & \text { THINK } & \text { OF } \\
\text { EXPERIENCING STRONGER EMOTIONS } & \text { THAN } \\
\text { REALITY } & \end{array}$ & 325 & 299 & 299 & Low Deviation \\
\hline 18 & $\begin{array}{l}\text { NOT ESPECIALLY GOOD AT MAKING OTHER } \\
\text { PEOPLE }\end{array}$ & 325 & 11 & 11 & High Deviation \\
\hline 19 & $\begin{array}{l}\text { HAVING STRONG } \text { REASONS FOR DOING } \\
\text { THINKS, CAN LOOK OTHERS IN THE EYE AND } \\
\text { LIE WITH A STRAIGHT FACE }\end{array}$ & 325 & 59 & 59 & High Deviation \\
\hline 20 & USUALLY FIRM IN PURSUING GOALS & 325 & 258 & 258 & High Deviation \\
\hline 21 & $\begin{array}{l}\text { AT A PARTY, KEEPING THE JOKES AND } \\
\text { STORIES ARE ENTERTAINED }\end{array}$ & 325 & 107 & 107 & High Deviation \\
\hline 22 & $\begin{array}{l}\text { NOT ALWAYS AN EASY PERSON, MOODY } \\
\text { SOMETIMES }\end{array}$ & 325 & 17 & 17 & High Deviation \\
\hline 23 & $\begin{array}{l}\text { KEEP MYSELF, IF PEOPLE DON'T RESPECT } \\
\text { OPINIONS }\end{array}$ & 325 & 119 & 119 & High Deviation \\
\hline 24 & 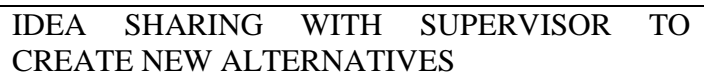 & 92.85 & 94.24 & 69.22 & Low Deviation \\
\hline 25 & 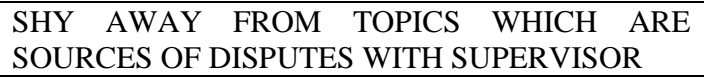 & 92.85 & 40.66 & 32.65 & High Deviation \\
\hline 26 & $\begin{array}{l}\text { MAKE OPTION KNOWN IN A DISAGREEMENT } \\
\text { WITH SUPERVISOR }\end{array}$ & 92.85 & 40.13 & 30.97 & High Deviation \\
\hline 27 & $\begin{array}{l}\text { SUGGEST SOLUTIONS WHICH COMBINE A } \\
\text { VARIETY OF VIEWPOINTS WITH SUPERVISOR }\end{array}$ & 92.85 & 73.08 & 64.4 & Low Deviation \\
\hline 28 & $\begin{array}{lccc}\text { STEER } & \text { CLEAR } & \text { OF } & \text { DISAGREEABLE } \\
\text { SITUATIONS WITH SUPERVISOR }\end{array}$ & 92.85 & 60.41 & 52.08 & High Deviation \\
\hline 29 & $\begin{array}{lcccc}\text { GIVE IN A LITTLE ON } & \text { IDEAS } & \text { WHEN } \\
\text { SUPERVISOR ALSO GIVES IN } & & \\
\end{array}$ & 92.85 & 51.98 & 47.8 & High Deviation \\
\hline 30 & $\begin{array}{l}\text { FEEL THAT THE DIFFERENCES ARE NOT } \\
\text { ALWAYS WORTH WORRYING } \\
\text { SUPERVISOR }\end{array}$ & 92.85 & 53.84 & 45.26 & High Deviation \\
\hline 31 & $\begin{array}{l}\text { INTEGRATE ARGUMENTS INTO A } \\
\text { A NEW } \\
\text { SOLUTIONS FROM THE ISSUES DISCUSSED }\end{array}$ & 92.85 & 51.73 & 45.83 & High Deviation \\
\hline 32 & $\begin{array}{l}\text { GO HALF-WAY FOR A SOLUTION } \\
\text { SUPERVISOR }\end{array}$ & 92.85 & 22.7 & 15.34 & High Deviation \\
\hline 33 & $\begin{array}{l}\text { ONCES STANDARDS ADOPTED IS STRONGLY } \\
\text { IF NECESSARY DEFEND WITH SUPERVISOR }\end{array}$ & 92.85 & 41.85 & 37.55 & High Deviation \\
\hline 34 & $\begin{array}{lrrr}\text { OFFER } & \text { CREATIVE } & \text { SOLUTIONS } & \text { IN } \\
\text { DISCUSSIONS } & \text { OF } & \text { DISAGREEMENTS } & \text { WITH } \\
\text { SUPERVISORS } & & & \\
\end{array}$ & 92.85 & 62.16 & 51.87 & High Deviation \\
\hline 35 & $\begin{array}{l}\text { KEEP QUIET ABOUT VIEWS IN ORDER TO } \\
\text { AVOID DISAGREEMENT WITH SUPERVISOR }\end{array}$ & 92.85 & 31.75 & 25.83 & High Deviation \\
\hline 36 & $\begin{array}{lcc}\text { FIND A COMPROMISE } & \text { SOLUTIONS } & \text { WITH } \\
\text { SUPERVISORS } & & \\
\end{array}$ & 92.85 & 63.95 & 60.12 & High Deviation \\
\hline 37 & $\begin{array}{lcccc}\text { DOWNPLAY } & \text { THE } & \text { IMPORTANCE } & \text { OF } & \text { A } \\
\text { DISAGREEMENT WITH SUPERVISOR } & & \\
\end{array}$ & 92.85 & 36.38 & 33.83 & High Deviation \\
\hline 38 & $\begin{array}{l}\text { REDUCE DISAGREEMENTS BY MAKING THEM } \\
\text { SEEM INSIGNIFICANT WITH SUPERVISOR }\end{array}$ & 92.85 & 47.29 & 42.1 & High Deviation \\
\hline 39 & $\begin{array}{l}\text { FIRM USUALLY PURSUE } \\
\text { GOALS WITH SUPERVISOR }\end{array}$ & 92.85 & 49.11 & 42.36 & High Deviation \\
\hline 40 & $\begin{array}{l}\text { PURSUE ARGUMENTS UNTIL SUPERVISOR } \\
\text { UNDERSTAND POSITION }\end{array}$ & 92.85 & 25.37 & 23.26 & High Deviation \\
\hline 41 & 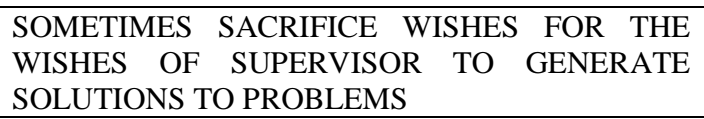 & 92.85 & 45.7 & 38.16 & High Deviation \\
\hline
\end{tabular}


IRA-International Journal of Management \& Social Sciences

\begin{tabular}{|c|c|c|c|c|c|}
\hline 42 & $\begin{array}{l}\text { OFFER TRADE-OFFS TO REACH SOLUTIONS } \\
\text { IN DISAGREEMENT WITH SUPERVISORS }\end{array}$ & 92.85 & 64.95 & 57.3 & High Deviation \\
\hline 43 & $\begin{array}{llll}\text { ARGUE INSISTENTLY FOR } & \text { STANCE } & \text { WITH } \\
\text { SUPERVISOR }\end{array}$ & 92.85 & 53.85 & 43.83 & High Deviation \\
\hline 44 & $\begin{array}{l}\text { SUPERVISORS CONFRONTS SUBORDINATES } \\
\text { ABOUT CONTROVERSIAL ISSUES }\end{array}$ & 92.85 & 40.6 & 34.16 & High Deviation \\
\hline 45 & $\begin{array}{llr}\text { PREFER NOT TO ARGUE BUT LOOK FOR THE } \\
\text { BEST SOLUTIONS POSSIBLE WITH } \\
\text { SUPERVISORS } & & \\
\end{array}$ & 92.85 & 40.04 & 35.26 & High Deviation \\
\hline 46 & $\begin{array}{l}\text { TRY TO SMOOTH OVER DISAGREEMENTS BY } \\
\text { MAKING THEM APPEAR UNIMPORTANT WITH } \\
\text { SUPERVISOR }\end{array}$ & 92.85 & 39.24 & 33.83 & High Deviation \\
\hline 47 & $\begin{array}{l}\text { INSIST POSITION BY ACCEPTING DURING A } \\
\text { DISAGREEMENT WITH SUPERVISORS }\end{array}$ & 92.85 & 46.65 & 40.4 & High Deviation \\
\hline 48 & $\begin{array}{l}\text { MAKE DIFFERENCE SEEMS LESS SERIOUS } \\
\text { WITH SUPERVISORS }\end{array}$ & 92.85 & 62.01 & 59.26 & High Deviation \\
\hline 49 & 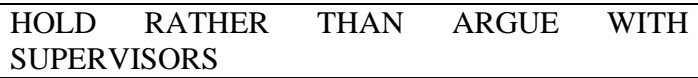 & 92.85 & 32.25 & 28.73 & High Deviation \\
\hline 50 & $\begin{array}{l}\text { CONFLICT BY CLAIMING DIFFERENCES ARE } \\
\text { TRIVIAL WITH SUPERVISOR }\end{array}$ & 92.85 & 47.4 & 39.79 & High Deviation \\
\hline 51 & $\begin{array}{lrrrr}\text { STAND FIRM } & \text { IN } & \text { EXPRESSING } & \text { VIEWPOINT } \\
\text { DURING A } & \text { DISAGREEMENT } & \text { WITH } \\
\text { SUPERVISOR } & & & \\
\end{array}$ & 92.85 & 50.95 & 42.4 & High Deviation \\
\hline
\end{tabular}

From the table it is depicted of the result values of mean, standard deviation, mean deviation technique among managers and executives opinions of both M/s Karvyand M/s AnandRathi respondents towards interpersonal conflict management. The result values of inferences are given in the table for every attribute. From the inferences it can be concluded saying that few aspects need to be improvised towards organizational performance by reducing conflicts among employees in the selected units under study. The parameters identified where they have high deviation among managerial \& executive positions respondents shows opinion deviation for respective attributes need a change in a strategic approach which results to performance.

\section{RECOMMENDATIONS OF THE STUDY}

- Treat Others Respectfully: One way of dealing with conflict have major impacts on the relationship between the results. People assess conflict behavior of others abilities. A person can manage conflict, respect for other person is must. If a man becomes very angry and even use violence to resolve conflict, people will condemn this person.

- Set the Right Tone for the Conversation: Tone of conversation throughout the conflict resolution process may have a huge impact. It is important to know that both sides have the will to resolve the conflict, rather than fighting. It can be a good diversion to spend some time on things unrelated to the conflict and expressing appreciation of counterpart's willingness to cooperate.

- Active Listening: One of the obstacles to solve a conflict efficiently is a human tendency to "listen ahead". This means that during a conversation one's own thoughts about what a speaker says cause us to jump to conclusions about what the person is trying to say. Once we think we "know" it, we do not further listen to what is really being said.

- Perspective Taking: Brown (1965) emphasizes that all successful interpersonal communication requires that the point of view of the other person be realistically understood, Perspective taking is largely an internal process, fostered by active listening, in which you try to understand how it might feel to be the other person in the situation. In other words, perspective taking is trying to understand the other person's needs concerns, difficulties, and pain in this situation to a similar extent as you understand your own needs, concerns, etc.

- Solve Conflicts When They Are Small: Many people think that the conflict will go away. In most cases, an untouched conflict over time, resentment and negative emotions will increase. Besides, when the emotions are intense, and the causes of the conflict are unclear because time has passed from the first incident, it is much more difficult to deal with. 
- Direct Discussion: Individuals involved in a conflict talk openly with one another about their perception of the problem, their feelings about it, and possible solutions. The conflict is clear and understood by the involved people. Resolution of the conflict is supported by the participants, since they came up with it.

- Policy and Procedures (Power or Authority): An authority, position, majority rule, or a persuasive minority settles the conflict. Power is used to impose a solution. When speed or efficiency is most important, this style may be effective. It also demonstrates the status of the person or group in authority.

- Do Nothing (Denial or Suppression): Person tries to solve problem by denying its existence. Differences are played down and surface harmony is preserved. If issue is relatively unimportant, this style allows a cooling off period or simply lets time "heal" the problem.

- Conflict prevention is often divided into two categories: direct prevention and structural prevention. Direct conflict prevention refers to measures that are aimed at preventing shortterm, often imminent, escalation of a potential conflict. Structural prevention focuses on more long term measures that address the underlying causes of a potential conflict along with potentially escalating and triggering factors

On the basis of our analysis of research studies conducted on the relationship between conflict management strategies and several aspects of organizational effectiveness, we can conclude that the problem - solving strategy or Behaviour may be viewed as the most effective way of managing conflicts in organizations, and it may be supplemented by the use of smoothing Behaviour. Thus, there is a need to encourage managers to enhance their utilization of these two conflict management strategies or methods, especially in the context of the emerging scenario of increasing education and skills.

\section{CONCLUSION}

Conflict escalation has according to this study it's foundation in emotional involvement. A person focused conflict has a higher risk of escalation and to evolve towards becoming dysfunctional. In comparison, task focused conflicts can lead to improved group functioning and decreased tension between members in the work team. Therefore the manager should get involved in task-focused conflicts to the extent that it benefits the work.

Through this study it has been revealed that conflict management can be divided into two areas, prevention of conflicts and management of functional conflicts. Feedback can be counted as preventive tools to help develop employees Behaviour and to ensure that the opinions and feelings are passed on through controlled communication channels. In order to resolve a conflict a conflict competent manager should be able to see the conflict from an independent perspective which was brought forward through the interviews and highlighted in the theoretical framework. In addition, the leader has to be able to decide the design of decision making processes, to determine if a quick timesaving decision should be taken or whether to involve the group and encourage fairness.

\section{REFERENCE}

1. Peter Wallensteen, Understanding Conflict Resolution War, Peace and The Global System (London: Sage Publishing, 2002), 16-17.

2. Leonard Rico, "Organizational Conflict: A Framework for Reappraisal," Industrial Management Review, Fall 1964, p. 67

3. Pondy LR, 1992. Reflections on organizational conflict. Journal of Organizational Behavior. 13: 257-261.

4. Tjosvold D, 1998. Cooperative and competitive goal approach to conflict: accomplishments and challenges. Applied Psychology: An International Review, 47 (3): 285-342.

5. Bankovskaya, V. (2012). Conflict Management strategies. Cambridge, MA: Harvard University press

6. Batool, H \& Riaz, S. (2013). Managing the conflict. A situational analysis of Organization in UAE. www.situationalanalvsis.com 
7. Birkhoff, J.E. (2013). Gender, conflict and conflict resolution. http://www.mediation.com/articles/birkhoff.cfm

8. Schwartz, S. J., Vignoles, V. L., Brown, R., \& Zagefka, H. (2014). The identity dynamics of acculturation and multiculturalism: Situating acculturation in context. In V. Benet-Martínez \& Y.-Y. Hong (Eds.), Oxford handbook of multicultural identity (pp.57-93). Oxford, UK: Oxford University Press.

9. Mooney, L. (2014). How does gender discrimination affect the work place? Yourbusiness.azcentral.com/gender-discriminationaffect-workplace-2546html

10. Miller and Vaske (2015) a k-means cluster analysis was performed on the non-motorized dataset. Unlike in those analyses, however, no convergence was reached with a 2, 3, or 4 cluster solution and therefore, the cluster analysis was not included in this analysis

11. USDA Forest Service. (2015, March). White River National Forest Official Webpage on Vail Pass Winter Recreation Area Retrieved from: http://www.fs.usda.gov/recarea/whiteriver/recreation/recarea/?recid=41445\&actid=92 